\title{
53. DATA REPORT: PALYNOLOGY OF SEDIMENTS FROM LEG 119 DRILL SITES IN PRYDZ BAY, EAST ANTARCTICA ${ }^{1}$
}

\author{
Elizabeth M Truswell ${ }^{2}$
}

\begin{abstract}
Samples from four drill sites in Prydz Bay, East Antarctica, were examined with the aim of determining the age of the oldest lithological units penetrated at each site. Lithological considerations have made age assessment difficult; most samples are diamictites, and contain several generations of pollen and spores which have been recycled from older deposits by glacial processes.

Palynomorphs identified fall into three major groups; Permian spores and pollen, Cretaceous and Tertiary spores and pollen, and early Tertiary dinoflagellates. At Site 740, where reddish and green sandstones and siltstones represent the oldest part of the drilled sequence, recovery of palynomorphs was too sparse to resolve the age of this unit. At Site 741 , grey sandstones and siltstones at the sampled base yielded an abundance of Early Cretaceous, probably Albian, spores and pollen; there is little evidence for a recycled origin. At Site 742 , the oldest sampled section yielded depauperate spore and pollen floras which are possibly Late Cretaceous in age, although rare Eocene dinoflagellates are present. Basal sediments at Site 739 are diamictites which contain sparse, apparently recycled floras, and must be as
young as Eocene or Oligocene.
\end{abstract}

\section{INTRODUCTION}

Twenty-five samples from four drill sites in Prydz Bay, East Antarctica, (Fig. 1) have been examined with the primary aim of determining the age of the oldest units penetrated at each site. This aim, however, was not realized with a high degree of confidence for reasons which are primarily concerned with the lithologies from which the palynomorph assemblages were recovered. A large number of the processed samples were diamictites, or closely associated with diamictites. These present the problem of containing several generations of microfossils, recycled from older deposits by processes operative at the base of grounded ice shelves.

The problem of deciding which of the identifiable suites of palynomorphs, separable on the basis of known age ranges of their component species, is actually in situ, has hampered age determinations during previous drilling in Antarctic waters. For example, doubts remain about the dating of units penetrated in DSDP sites in the Ross Sea (Kemp, 1975; Kemp and Barrett, 1975), and in ice-platform drilling in McMurdo Sound (Truswell, 1968; Mildenhall, 1987).

In the Prydz Bay sites, three main palynomorph groups are discernible. These are Permian palynomorphs (mainly striate, bisaccate pollen); spores and pollen which are for the most part long-ranging in the Cretaceous and Tertiary; and a suite of dinoflagellates, with age ranges of Eocene to early Oligocene, which were apparently endemic to Antarctic, or to high-latitude waters during that interval. The same three major components characterize modern bottom sediments around a wide span of East Antarctica (Truswell, 1983). However, at two of the sites (741 and 742), more distinctive suites suggested to be of Early and Late Cretaceous age were identified.

\section{SUMMARY OF RESULTS}

In the present cruise leg, the oldest part of the section within Prydz Bay was that drilled at Site 740. Reddish and green sand-

\footnotetext{
${ }^{1}$ Barron, J., Larsen, B., et al., 1991. Proc. ODP, Sci. Results, 119: College Station, TX (Ocean Drilling Program).

2 Bureau of Mineral Resources, PO Box 378, Canberra, ACT 2601, Australia.
}

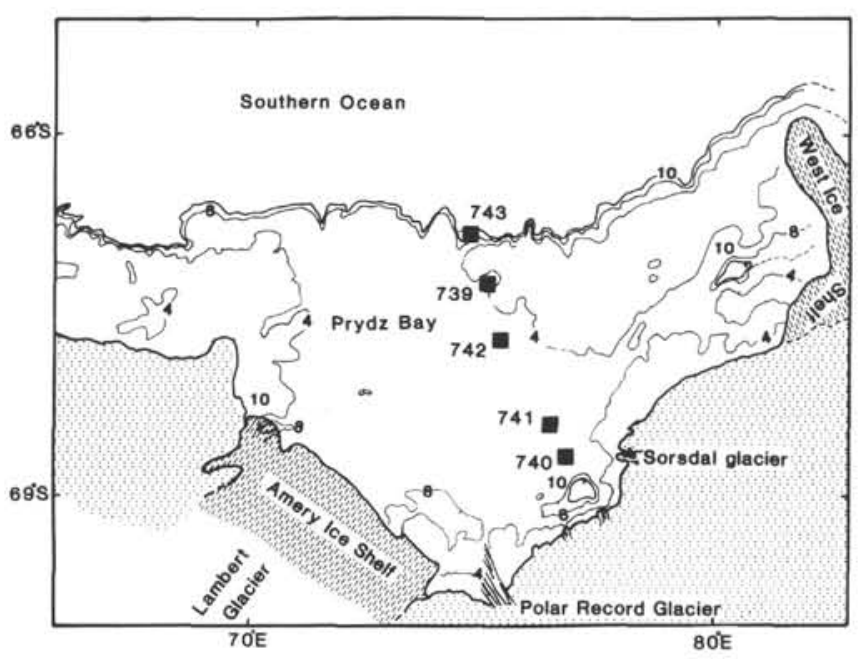

Figure 1. Prydz Bay, showing location of drill sites (from Jenkins and Alibert, this volume). Contour interval is in hundreds of meters.

stones and lesser siltstones at this site were palynologically unpromising, being both too coarse and too weathered for palynomorph preservation. Yield from these was, as expected, extremely meager, and the few palynomorphs recovered were of mixed age and provenance and could well be contaminants from further up the hole.

At Site 741, which sampled younger units in the seaward-dipping sequence, grey sandstones and siltstones at the base of the section yielded the most confidently dated samples of all. Wellpreserved assemblages of spores and pollen here contain a number of species known to be confined to the Albian in Australia. Most of the associated long-ranging forms are compatible with such an age assignment. Even here, however, there are a very few grains (significantly less than $1 \%$ ) which are younger, i.e., of early Tertiary age. These have been interpreted as contaminants, but some doubt must remain about age assignments at this site.

At Site 742 , the oldest samples contained assemblages with no evidence of recycling or of mixed assemblages. These con- 
tained nonmarine spore and pollen suites which could be interpreted as Late Cretaceous, but the floras are depauperate by comparison with those known from the Antarctic Peninsula. Shipboard studies showed samples from the same interval to contain some of the Eocene dinoflagellate suite, so again, a doubt remains as to the age assignment.

At Site 739, the oldest units are diamictites, and contain floras that are apparently recycled. They contain all three of the major palynomorph elements, i.e., Permian pollen, long-ranging Cretaceous-Tertiary pollen, and species of the endemic Antarctic Eocene dinoflagellate flora. The age of these basal diamictites must be as young as the youngest component, i.e., of Eocene to perhaps Oligocene age, but it could be younger than this.

\section{DETAILED PALYNOLOGY OF DRILL SITES}

\section{Site 740}

Site 740 was drilled in the inner part of Prydz Bay, at $68^{\circ} 41.220^{\prime} \mathrm{S}, 76^{\circ} 43.246^{\prime} \mathrm{E}$, in $816 \mathrm{~m}$ of water. Its purpose was to date the oldest part of the sequence overlying the basement in the eastern part of Prydz Bay, and possibly to constrain the age of formation of the Lambert Graben.

Seven samples were analyzed palynologically from this site, and all were from the oldest lithological unit, Unit III, which is a green and reddish sandstone, alternating with siltstones and claystones. It has been suggested that this unit may be as old as Permian, on the basis of its suggested correlation with the Amery Group of the Prince Charles Mountains, or that it may be of Mesozoic or Cenozoic age. With respect to the latter suggestion, it may be worth noting the lithological resemblance between this unit and the Early Jurassic Cockleshell Gully Formation of the Perth Basin of Western Australia.

Unfortunately, palynology has been unable to resolve the age of this unit. Although the siltiest, and least weathered, lithologies were selected for preparation, recovery of palynomorphs was too sparse to be confident that the microfossils were in situ, and not contaminants from further up the hole, or from nearsurface muds, which are frequently rich in recycled material.

Details of individual samples are given below:

\section{A-19R-1, 104-111 cm. Preparation MFP 9114}

Residue nearly barren, except for very sparse woody fragments, and broken specimens of Osmundacidites wellmanii Couper Cyathidites sp., and Microcachryidites antarcticus Cookson, all of which are long-ranging Jurassic-Cretaceous taxa.

\section{A-20R-CC. Preparation MFP 9115}

Residue nearly barren, except for fragments of Permian striatitid pollen grains (Protohaploxypinus spp.) and rare Nothofagidites (probably Tertiary).

\section{A-22R-2, 87-90 cm. Preparation MFP 9099}

A very sparse yield of pollen grains, which are all Cretaceous-Tertiary forms. They were: Nothofagidites $\mathrm{sp}$. cf. emarcidus, Phyllocladidites sp., Araucariacites sp., Cicatricosisporites sp., Haloragacidites sp., and Microcachryidites antarcticus.

\section{A-25R-CC. Preparation MFP 9109}

On maceration the sample yielded only a small quantity of woody debris.

\section{A-27R-CC. Preparation MFP 9080}

Entirely barren.

740A-29R-2. Preparation MFP 9116

The sample yielded sparse woody debris, plus the following pollen grains, which are long-ranging in the Late CretaceousTertiary: Podocarpidites sp. Nothofagidites emarcidus (Cookson), and Haloragacidites harrisii (Couper).

\section{Site 741}

Site 741 is situated on the inner part of Prydz Bay, on the East Antarctic continental shelf $\left(68^{\circ} 23.160^{\prime} \mathrm{S}, 76^{\circ} 23.020^{\prime} \mathrm{E}\right)$ in $561 \mathrm{~m}$ water depth. Nine samples from this site were examined palynologically; all were from the deepest lithological unit, Unit IV, a grey sandstone and siltstone with minor quartz fragments. Details of the palynomorph recovery from the samples examined are set out below.

\section{A-7R-CC. Preparation MFP 9102}

Organic residues obtained were very meager; very rare, long ranging pollen types were observed, including Nothofagidites spp. (brassii type, cf. $N$. emarcidus) and Podocarpidites sp. The Nothofagidites species suggest an age range of Late Cretaceous to Neogene.

\section{A-8R-CC. Preparation MFP 9103}

The sample yielded an abundance of finely divided woody fragments, and rare, poorly preserved spores and pollen. All of the spores and pollen observed were consistent with an Early Cretaceous age. They included: Cicatricosisporites australiensis (Cookson), Classopollis sp., Cyathidites australis Couper, Microcachryidites antarcticus, Perotrilites jubatus (Dettmann \& Playford), Podocarpidites sp., and Rouseisporites reticulatus Pocock. In addition, megaspore fragments referable possibly to Balmeisporites were observed. All palynomorphs were nonmarine in origin.

\section{A-10R-1, 27-29 cm. Preparation MFP 9104}

This sample yielded only finely divided wood fragments, which were present in abundance.

\section{A-12R-2, 31-34 cm. Preparation MFP 9105}

Again, abundant woody fragments were present in this sample. Cuticle fragments were also common. Spores and pollen were present, but all were thin and poorly preserved. All were consistent with an Early Cretaceous age. Observed were: $A p$ pendicisporites sp. cf. A. distocarinatus Dettmann \& Playford Cyathidites minor Couper, Microcachryidites antarcticus, and Podocarpidites spp. Fungal resting spores were also common. All spores were orange-brown in color, as in samples above and below.

\section{A-13R-1, 105-107 cm. Preparation MFP 9106}

Abundant fine wood was present in residues from this sample. Sparse spores and pollen were poorly preserved and only Classopollis sp., Osmundacidites sp., and Podocarpidites spp. were identified. All are consistent with an Early Cretaceous age. 
741A-13R-3, 43-46 cm. Preparation MFP 9107

Residues were very similar to those from the sample above, with abundant woody debris. Appendicisporites sp. cf. A. distocarinatus, Ceratosporites equalis Cookson \& Dettmann, and Gleicheniidites sp. were identified, all of which are confined to, or common in, Early Cretaceous sediments.

\section{A-13R-4, 12-15 cm. Preparation MFP 9095}

Plant tissues were common in the residue from this sample, and included wood fragments and cuticle. Spore and pollen preservation was better than in any other sample from this site, and the following were identified: Aequitriradites spinulosus (Cookson \& Dettmann), Appendicisporites sp. cf. A. distocarinatus (this species is thicker-walled, with longer apical projections than $A$. distocarinatus), Cicatricosisporites australiensis, C. hughesii Dettmann, Classopollis sp., Coptospora paradoxa (Cookson \& Dettmann), Cyathidites minor, Foraminisporis asymmetricus (Cookson \& Dettmann), Laevigatosporites sp., Microcachryidites antarcticus, Osmundacidites wellmanii, Rouseisporites reticulatus, and Podocarpidites spp.

All of the above-named species are consistent with an Early Cretaceous age. More specifically, the presence of Coptospora paradoxa, of which several specimens were observed, indicates that the age of the spore component is likely to be as young as middle Albian, from what is known of spore ranges in southern Australia (Dettmann, 1986). The abundance of Appendicisporites type spores is broadly consistent with this, although in Australia this morphotype becomes most common in rocks slightly younger than this, i.e., in the Cenomanian (Helby et al., 1987). The whole spore association suggests the Coptospora paradoxa Zone, which in Australia has a middle to late Albian age range (Helby et al., 1987). The only taxon at odds with this assignment is Cicatricosisporites hughesii, which does not overlap with $C$. paradoxa in the Gippsland and Otway Basins according to Dettmann (1986), although Burger (1980) shows an overlap of the species ranges in the Surat and Eromanga Basins to the north.

While the majority of the palynomorphs recovered from this sample are consistent with an Early Cretaceous, and probably with an Albian age, a few grains (less than $1 \%$ of the total observed) were of younger derivation. These included grains of Nothofagus brassii type, and some tricolpate angiosperms. All of these suggest a Tertiary origin.

\section{A-13R-CC. Preparation MFP 9079}

Residues from this sample yielded an abundance of dark woody fragments and very rare spores and pollen. These included Cicatricosisporites australiensis and Podocarpidites $\mathrm{sp}$. both of which are consistent with a Cretaceous age.

\section{A-14R-CC. Preparation MFP 9096}

Woody debris was present in this sample. Spores and pollen were sparse but showed reasonable preservation. All taxa are consistent with an Early Cretaceous (Albian) age, and included the following: Appendicisporites sp. cf. A. distocarinatus, Classopollis sp., Ceratosporites equalis, Cyathidites australis, Coptospora paradoxa, Kraeuselisporites linearis (Cookson \& Dettmann), Osmundacidites wellmanii, Rouseisporite reticulatus, and Microcachryidites antarcticus.

\section{Site 741 Summary}

The basal lithological unit at this site yielded predominantly Early Cretaceous spores, and these were consistent with a rela- tively narrow age range, on the basis of ranges known from Australia. There is a very small component of pollen types of younger age in some samples; these are mostly specimens of Nothofagus brassii type pollen, which is long ranging through the latest Cretaceous and Tertiary. Two interpretations of the mixed nature of these assemblages are possible; firstly, they may be of early Tertiary age, and the Early Cretaceous component is recycled from older sediments, or alternatively, they may be of Early Cretaceous age, and the minor younger component represents a contamination from higher up the hole. While it remains possible that the dominant component, i.e., the Early Cretaceous spores and pollen, are indeed recycled (and massive recycling is reported from the palynological literature; see, for example, Ingram, 1967), I prefer the second interpretation, that the sequence sampled is of Early Cretaceous age, and the Tertiary forms are contaminants. This seems more satisfactory because the Cretaceous spores and pollen are all compatible with assemblages known from a relatively narrow time interval in Australia-the Coptospora paradoxa Zone, of the middle to late Albian. A reworked assemblage might be expected to carry spores diagnostic of a wider age range. Also, all spores show a similar level of organic maturation, and are of a uniform orange-brown color.

The sequence sampled appears to be entirely nonmarine, and is distinguished by a considerable input of fine plant debris, mainly wood.

\section{Site 742}

This site is situated in the middle part of the Prydz Bay shelf, at $67^{\circ} 32.98^{\prime} \mathrm{S}, 75^{\circ} 24.27^{\prime} \mathrm{E}$ in $410 \mathrm{~m}$ of water. The lithologies encountered were a series of diamictites. Five samples were analyzed palynologically, from the deeper Units V and VI.

\section{A-20R-3, 61-63 cm. Preparation MFP 9109}

Recovery was sparse from this core, with little organic debris. Most common were dinoflagellates belonging to a flora that appears to have been provincial around Antarctica in the Eocene, and which Wrenn and Hart (1988) have described comprehensively from Seymour Island. Species of this flora observed in this sample include Senegalinium asymmetricum (Wilson), Impagidinium victorianum (Cookson \& Eisenack), and Vozzhennikovia apertura (Wilson). Long-ranging Late Cretaceous to Tertiary spore and pollen species, including Gleicheniidites circiniidites (Cookson) and Nothofagidites of the brassii type were also present, as were the Permian striatitid pollen Striatopodocarpidites fusus (Balme \& Hennelly) and Protohaploxypinus (Balme \& Hennelly).

The age of the assemblage must be Eocene or younger.

\section{A-22R-1. Preparation 9108}

This assemblage was striking in its domination by Permian forms, chiefly striatitid pollen, which was poorly diversified, although present in considerable abundance. The proportion of striate species, obviously recycled here, is very similar to that observed in late Permian assemblages from the Amery Formation of the Prince Charles Mountains (Balme and Playford, 1967; Kemp, 1973; and Dibner, 1978), and which may be a source for the recycled material in Prydz Bay. Permian species observed included Protohaploxypinus limpidus (Balme \& Hennelly), P. amplus, Striatopodocarpidites fusus, Scheuringipollenites sp., Densipollenites indicus Bharadwaj, and Granulatisporites micronodosus Balme \& Hennelly. Dinoflagellates of the provincial Eocene flora were less common, and included $\mathrm{De}$ flandrea antarctica Wilson, Deflandrea sp. cf. D. dartmooria (Cookson \& Eisenack) and Vozzhennikovia apertura. Long- 
ranging pollen types, chiefly Nothofagidites, were rare, as were spores of the dominantly Early Cretaceous Cicatricosisporites australiensis.

\section{A-33R-6. Preparation MFP 9110}

Recovery was very sparse from this sample, but the palynomorphs recovered fell into the same three categories as described for the samples above, i..e., late Permian pollen, dinoflagellates of essentially Eocene age, and pollen and spores which are generally long ranging but of Cretaceous-Tertiary age, Permian pollen species included Striatopodocarpidites fusus, Protohaploxypinus sp. and Falcisporites sp. The Eocene dinoflagellates included Spinidinium macmurdoense (Wilson) Vozzhennikovia apertura, Deflandrea antarctica, and Senegalinium asymmetricum. The long-ranging spore and pollen component comprised Microcachryidites antarcticus, Gleicheniidites sp., Triporollenites sp., and, as a rare component, Callialasporites dampieri (Balme) which is a Jurassic to Early Cretaceous species.

\section{A-34R-6, 32-33 cm. Preparation MFP 9112}

Recovery from this sample differed markedly from those above, in that all palynomorphs belonged to a single time interval, probably Late Cretaceous. There were no recycled Permian pollen, nor were any dinoflagellates observed; the environment appears to have been entirely nonmarine.

Spores and pollen dominate, and were abundant. Species observed included Phyllocladidites mawsonii Cookson, Cicatricosisporites australiensis, Stereisporites sp., Microcachryidites antarcticus, Podocarpidites sp., Kraeuselisporites majus (Cookson \& Dettmann) Gleicheniidites circiniidites, Osmundacidites wellmanii, Laevigatosporites ovatus, Reticulumsporites sp. cf. $R$. arcus (Balme), and Retitriletes reticulumsporites (Rouse). These forms are essentially long-ranging in the Cretaceous, but it should be noted that $P$. mawsonii, which is akin to the pollen of the modern Huon Pine, Lagarostrobus, begins its range in the Turonian in Australia and New Zealand (Playford and Dettmann, 1978: Raine, 1984), and is abundant in the Late Cretaceous of the Antarctic Peninsula (Dettmann and Thomson, 1987).

It is possible that this assemblage is thus Turonian or younger in age. The presence of a spore species morphologically very close to Camarozonosporites bullatus Harris may support such an age, as this species appears first in the Santonian in Australia (Helby et al., 1987). Some pollen of Nothofagus brassii type is present, but is difficult to assign to known species. Phimopollenites sp. cf. $P$. pannosus is another observed species which would accord with a Late Cretaceous age. If such an age assignment is indeed correct, then the flora is a very depauperate one by comparison with those of southern Australia, and those from the Antarctic Peninsula, which are characterized by a much higher diversity of angiosperm pollen, especially triporate species indicative of a proteaceous parentage.

It is of interest to note that the shipboard report for this core section at $116 \mathrm{~cm}$ also suggested a Late Cretaceous age, although the core section immediately above contained rare Eocene dinoflagellates. On the evidence presented here, a Late Cretaceous age seems most likely.

\section{A-34R-6, 41-44 cm. Preparation MFP 9111}

This sample yielded essentially the same assemblage as that described above, but with palynomorphs much less well preserved.

\section{Site 742 Summary}

The samples analyzed here suggest that the assemblages from Lithological Unit V are essentially recycled. The youngest identifiable palynomorph suite in them is the dinoflagellate assemblage which is composed of species restricted to high southern latitudes. This assemblage was first identified by McIntyre and Wilson (1966) in McMurdo Sound erratics, and has subsequently been described from a number of sites; its composition and distribution was most recently reviewed by Wrenn and Hart (1988). The age range of its most common species is Eocene to early Oligocene. It should be noted that dinoflagellates younger than this have not been described from Antarctica. It is entirely possible that the sequences penetrated in Prydz Bay, which carry this dinoflagellate signature, are younger than Eocene-Oligocene, but lack an in situ flora, and contain only recycled older forms.

The samples from Unit V also contain a high frequency of recycled Permian pollen; the composition of this is very close to late Permian pollen suites from the Amery Formation of the Prince Charles mountains.

Two samples from Unit VI at this site contain assemblages of very different aspect from those above. No obviously recycled species were observed, nor were there any dinoflagellates. The overall aspect of the spore and pollen suites suggests a Late Cretaceous age, with depauperate floras.

\section{Site 739}

Site 739 was drilled in a thick sequence of glacial sediments in the outer part of Prydz Bay at $67^{\circ} 16.570^{\prime} \mathrm{S}, 75^{\circ} 4.914^{\prime} \mathrm{E}$ in $412 \mathrm{~m}$ of water. The four samples examined palynologically all come from the deepest sedimentary unit, Unit V, described as a massive diamictite. Shipboard reports note the paucity of organic matter in residues from this site; this observation was borne out by the present investigation.

\section{A-41R-3, 42-46 cm. Preparation MFP 9097}

The sample yielded a small amount of woody debris and some cuticle. The most common palynomorphs were Permian striate pollen, including the species Protohaploxypinus amplus, P. limpidus, Striatopodocarpidites fusus, and Scheuringipollenites sp., and the spore Granulatisporites micronodosus. Also observed were rare Eocene dinoflagellates, including Deflandrea sp. cf. D. dartmooria and Turbiosphaera filosa (Wilson).

\section{A-46R-2, 19-21 cm. Preparation MFP 9093}

A small quantity of finely comminuted wood was all that was recovered from this sample.

\section{A-47R-1, 90-93 cm. Preparation MFP 9098}

The sparse recovery of palynomorphs from this sample included a mix of Permian pollen (Striatopodocarpites fusus, Protohaploxypinus limpidus), a Cretaceous spore (Appendicisporites sp. cf. $A$. distocarinatus), and an Eocene dinoflagellate (Vozzhennikovia apertura).

\section{A-51R-2. Preparation MFP 9004}

A mixed, largely recycled, assemblage was recovered from this sample. Identified were: Protohaploxypinus amplus, $P$. limidus, Striatopodocarpites fusus (Permian) Classopollis sp. (Jurassic-Early Cretaceous), Phyllocladidites mawsonii, Haloraga- 
cidites harrisii, Nothofagidites $\mathrm{sp}$. cf. $N$. falcatus Proteacidites sp. $\mathrm{cf}$. $P$. rectomarginis (Late Cretaceous-Oligocene, dinoflagellates).

\section{Site 739 Summary}

Recovery of palynomorphs from this site was consistently sparse, and all assemblages recovered were of mixed age and provenance, with Permian, Cretaceous, and Tertiary elements present. The only stratigraphically restricted forms which are possibly in situ are the species belonging to the endemic Antarctic flora referred to above. The presence of these forms, which have an Eocene to early Oligocene range, accords with the shipboard report of late Eocene to early Oligocene calcareous nannoplankton from Core 739-46R.

\section{REFERENCES}

Balme, B. E., and Playford, G., 1967. Late Permian plant microfossils from the Prince Charles Mountains, Antarctica. Rev. Micropaleontol., 10:179-192.

Burger, D., 1980. Palynology of the Lower Cretaceous of the Surat Basin. Bull. Bur. Miner. Resour. Geol. Geophys. Aust., 189:1-106.

Dettmann, M. E., 1986. Early Cretaceous palynoflora of subsurface strata correlative with the Koonwarra Fossil Bed, Victoria. Mem. Assoc. Australas. Palaeontol., 3:79-110.

Dettmann, M. E., and Thomson, M.R.A., 1987. Cretaceous palynomorphs from the James Ross Island area, Antarctica-a pilot study. Bull. Br. Antarct. Surv., 77:13-59.

Dibner, A. F., 1978. Palynocomplexes and age of the Amery Formation deposits, East Antarctica. Pollen et Spores, 20:405-422.

Helby, R., Morgan, R., and Partridge, A. D., 1987. A palynological zonation of the Australian Mesozoic. In Jell, P. A. (Ed.), Studies in Australian Mesozoic Palynology. Mem. Assoc. Australas. Palaeontol., 4:1-94.
Ingram, B. S., 1967. Palynology of the Otorowiri Siltstone member, Yarragadee Formation. West. Annu. Rep. Geol. Surv. West. Aust., $1966,79-82$.

Kemp, E. M., 1973. Permian Flora from the Beaver Lake Area, Prince Charles Mountains, Antarctica, I. Palynological examination of samples. Bull. Bur. Miner. Resour. Geol. Geophys. Aust., 126:7-12. 1975. Palynology of Leg 28 drill sites, Deep Sea Drilling Project. In Hayes, D. E., Frakes, L. A., et al., Init. Repts. DSDP, 28: Washington (U.S. Govt. Printing Office), 599-623.

Kemp, E. M., and Barrett, P. J., 1975. Antarctic glaciation and Early Tertiary vegetation. Nature, 258:507-508.

McIntyre, D. J., and Wilson, G. J., 1966. Preliminary palynology of some Antarctic Tertiary erratics. N. Z. J. Bot., 4:315-321.

Mildenhall, D. C., 1987. CIROS 1 drillhole, McMurdo Sound, Antarctica: terrestrial palynology. New Zealand activities in Antarctica 1986-1987. Prog. and Abstr. Antarctica Res. Ct., Victoria Univ., Wellington.

Playford, G., and Dettmann, M. E., 1978. Pollen of Dacrydium franklinii Hook. f. and comparable Early Tertiary microfossils. Pollen et Spores, 20:513-534.

Raine, J. I., 1984. Outline of a palynological zonation of Cretaceous to Paleogene terrestrial sediments in west coast region, South Island, New Zealand. Rep. N. Z. Geol. Surv., 109:1-82.

Truswell, E. M., 1983. Recycled Cretaceous and Tertiary pollen and spores in Antarctic marine sediments: a catalogue. Paleontographica $B, 186: 121-174$.

1986. Palynology. In Barrett, P. J. (Ed.), Antarctic Cenozoic History from the MSSTS-1 Drillhole, McMurdo Sound: Victoria, New Zealand (Antarctic Research Centre), 237:131-134.

Wrenn, J. H., and Hart, G. F., 1988. Paleogene dinoflagellate cyst biostratigraphy of Seymour Island, Antarctica. Mem. Geol. Soc. Am., 169:321-447.

Date of initial receipt: 1 February 1990

Date of acceptance: 24 July 1990

Ms 119B-162 